\title{
Modeling Stream Flow Using SWAT Model in the Bina River Basin, India
}

\author{
Fitsum T. Teshome ${ }^{1,2^{*}}$, Haimanote K. Bayabil2, L. N. Thakural’3, Fikadu G. Welidehanna² \\ ${ }^{1}$ Department of Plant Science, College of Agriculture and Natural Resources, Madda Walabu University, Bale-Robe, Ethiopia \\ ${ }^{2}$ Department of Agricultural and Biological Engineering, Tropical Research and Education Center, IFAS, University of Florida, \\ Homestead, FL, USA \\ ${ }^{3}$ Surface Water Hydrology Division, National Institute of Hydrology, Roorkee, India \\ Email: ^fteshome@ufl.edu
}

How to cite this paper: Teshome, F.T., Bayabil, H.K., Thakural, L.N. and Welidehanna, F.G. (2020) Modeling Stream Flow Using SWAT Model in the Bina River Basin, India. Journal of Water Resource and Protection, 12, 203-222.

https://doi.org/10.4236/jwarp.2020.123013

Received: December 31, 2019

Accepted: March 2, 2020

Published: March 5, 2020

Copyright (C) 2020 by author(s) and Scientific Research Publishing Inc. This work is licensed under the Creative Commons Attribution International License (CC BY 4.0).

http://creativecommons.org/licenses/by/4.0/ Open Access

\begin{abstract}
Understanding watershed runoff processes is critical for planning effective soil and water management practices and efficiently utilize available water resources. The main objective of this study was to investigate the performance of the Soil and Water Assessment Tool (SWAT) to simulate streamflow from the Bina basin in the Madhya Pradesh state of India. The SWAT model was calibrated and validated on a daily and monthly basis using historical streamflow and weather data from the Bina basin. The Sequential Uncertainty Fitting (SUFI-2) technique in the SWAT Calibration and Uncertainty Procedures (SWAT-CUP) program was used to assess model uncertainties. The SWAT model performed "satisfactory" and "very good" in simulating streamflow at daily and monthly time steps, respectively. Model calibration results showed that coefficients of determination $\left(\mathrm{R}^{2}\right)$ values were 0.66 and 0.96 ; while Nash-Sutcliffe (NSE) values were 0.65 and 0.94 for daily and monthly simulations, respectively. The $\mathrm{R}^{2}$ values of daily and monthly simulations during model validation were 0.65 and 0.72 , respectively while the respective NSE values were 0.58 and 0.72 . This study demonstrated that the SWAT model could be effectively used to simulate streamflow in the Bina river basin.
\end{abstract}

\section{Keywords}

Modeling, Streamflow, SWAT, SWAT-CUP, Bina River Basin

\section{Introduction}

River basins are important hydrological and environmental improvements, and if managed properly, they generate steady streamflow from baseflow and runoff. 
Runoff is the water flow that occurs when soil is saturated and excess water from rain, snowmelt, or other sources flows over the land surface and is a major component of the hydrologic cycle [1]. As with all characteristics of the water cycle, the interaction between precipitation and runoff varies according to time and location [2]. Runoff plays a crucial role in the hydrological cycle by discharging excess precipitation to the oceans to control the amount of water flows into streams [3]. The water balance equation describes the hydrological cycle by accounting for the flow of water into and out of a system for a specific period of time [4].

The rainfall-runoff model is extensively used in hydrology. Runoff signal which leaves the watershed from the rainfall signal received by the basin is determined by the rainfall-runoff model [5]. Rainfall-runoff model mathematically represents rainfall-runoff relations of a catchment area, drainage basin or watershed [6]. This mathematical representation is used for simplification of the actual process of runoff in nature.

The main purpose of hydrological modeling is to quantify the hydrologic response of a watershed to climatic parameters, soils, land use, and management conditions; this, in turn, plays a significant role in water resources planning, flood forecasting, pollution control, and numerous other applications [7]. Several methods have been developed by different researchers to simulate the rainfall-runoff process.

The Soil and Water Assessment Tool (SWAT) is a watershed scale model developed by United States Department of Agriculture, Agricultural Research Service (USDA-ARS) for predicting the impact of land management practices on water, sediment and agricultural chemical yields, runoff, water balance of a large basin in a complex watershed with varying soils, land use, and management conditions over long period of time [8].

Similarly, several model calibration techniques exist for model optimization and uncertainty analysis such as the sequential uncertainty fitting (SUFI-2) program in the SWAT Calibration Uncertainty Procedures (SWAT-CUP). The SWAT-CUP is a public domain computer program for the calibration of SWAT models. SWAT-CUP contains Generalized Likelihood Uncertainty Estimation (GLUE), Parameter Solution (Parasol), and Sequential Uncertainty Fitting (SUFI-2) [9]. The SWAT-CUP enables sensitivity analysis, calibration, validation and uncertainty analysis of the SWAT model. SUFI-2 combines calibration and uncertainty analysis to find parameter uncertainties while calculating the smallest possible prediction uncertainty range. Hence, these parameters uncertainty reflect all sources of uncertainty [10]. In SUFI-2, the uncertainty of input parameters is depicted as a uniform distribution, while model output uncertainty is quantified at the $95 \%$ prediction of uncertainty (95PPU).

SWAT-CUP includes parallel processing, visualization of outlet location using Bing Map, the creation of multi-objective function, extraction, and calculation of 95PPU for all variables into output. rich, output.hru, output.sub files without 
measurements and one-at-a-time sensitivity analysis [9]. The main objective of this study was to investigate the performance of the SWAT model in simulating streamflow from the Bina basin in the Madhya Pradesh state of India.

\section{Materials and Methods}

\subsection{Description of the Study Area}

This study was conducted in the Bina river basin, which has a total catchment area of $2822 \mathrm{~km}^{2}$ (Figure 1). Bina river, the main river in Bina basin, is among important tributaries of the Betwa River system (Figure 1) which drains part of the Madhya Pradesh and Uttar Pradesh which originates from the Begumganj block of Raisen district and enters Sagar district at Rahatgarh block and traverses through Kura and Bina tehsil before the confluence with river Betwa near Basoda town in Vidisha district [11]. Bina basin falls between $23^{\circ} 3^{\prime}$ to $24^{\circ} 3^{\prime} \mathrm{N}$ and $78^{\circ} 1^{\prime}$ to $78^{\circ} 6^{\prime} \mathrm{E}$. The catchment area is highly undulated and covered by forests, barren lands, and localized rain-fed agriculture. The stream density is more in the upper catchment as compared to the lower part of the river basin, the later mostly gentle sloping to plain topography mostly covered with agricultural fields, the streams are dry after the monsoon months (June to September).

\subsection{Input Data}

Input data for SWAT include spatial maps of Digital Elevation Model (DEM), soil information, and land use land cover. In addition, daily weather data (precipitation, and minimum and maximum air temperature, relative humidity, average wind speed, and solar radiation) were used for simulating the streamflow. River discharge was also used for model calibration and validation purposes.

\subsubsection{Spatial Data}

1) Land use and land cover and Soil Map

Landsat 8 ETM+ with a $30 \mathrm{~m}$ resolution for Path/Row: 145/043 and 145/044

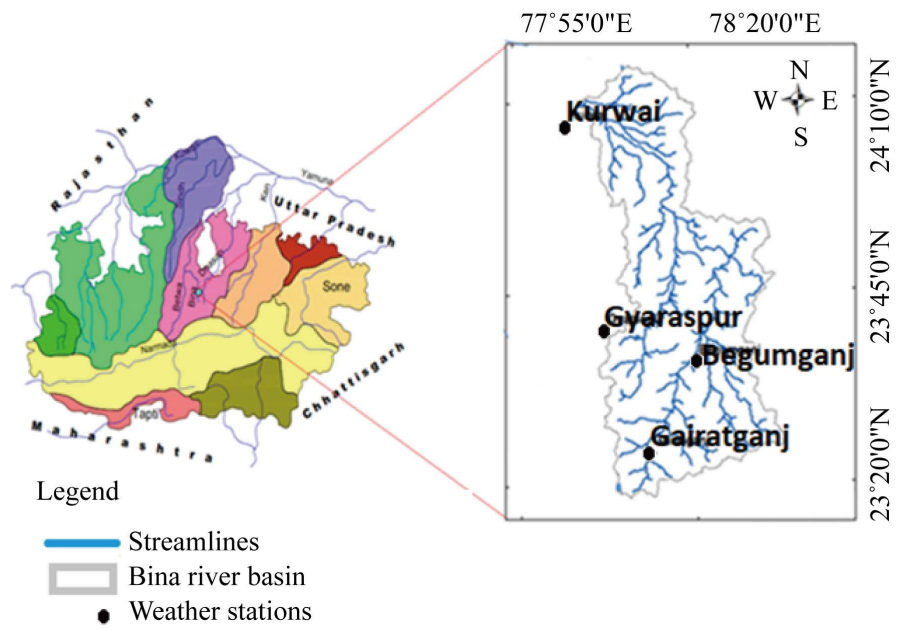

Figure 1. Madhya Pradesh River Basins (source [12]). 
retrieved on 6 March 2015 was used. The images were retrieved from the USGS' EarthExplorer site (https://earthexplorer.usgs.gov/). Landsat 8 ETM+ satellite images with optical bands with the standard false-color combinations were used to prepare the land use and land cover map of the basin, for which subsequent ground truth verification was carried out through extensive field visits. For the land use land cover, supervised classification using maximum likelihood classifier was applied. Land use and land cover spatial data were reclassified into SWAT land cover/crop types.

Soil toposheets with sheet numbers of 1, 2, 4, and 5 prepared by the Indian Council of Agricultural Research-National Bureau of Soil Survey \& Land Use Planning (ICAR-NBSS \& LUP) on a scale of 1:250,000 and printed on a scale of 1:500,000 were used to prepare soil map of the watershed. The soil map was linked with the user soil database. A user lookup table was created that identifies the SWAT code for the different categories of soil and land use a land cover on the map as per the required format.

2) Aster Global Digital Elevation Model Version 002 (ASTER GDEM v2)

The digital elevation model of $30 \mathrm{~m}$ spatial resolution was downloaded from the EarthExplorer website (https://earthexplorer.usgs.gov/) and used to delineate the watershed and to analyze the drainage patterns of the land surface terrain.

\subsubsection{Weather and Hydrological Data}

Daily streamflow, precipitation, air temperature (maximum and minimum), relative humidity, average wind speed and solar radiation from the Bina basin were used for the period 1989-1996. These data were collected from Madhya Pradesh State Data Center (MPSDC), Bhopal. The daily weather data and weather generator location (wgnloc) were prepared into a separate excel sheet and converted into .dbf format using Microsoft access before imported into the model setup. The model was set up with a two-year warmup period. Model calibration was conducted using data from 1991 to 1993 while data from 1994 to 1996 was used for validation.

\subsubsection{Model Setup}

All spatial data inputs (DEM, land use the land cover map, and soil map) were projected to Universal Transverse Mercator (UTM) 43 North and World Geodetic System (WGS) 84 datum and were resampled to a 30-pixel size using Bilinearresampling technique in ArcGIS 10.5.1. The Soil and Water Assessment Tool (Arc SWAT 2012.10.4.21) interfaced with Arc GIS 10.5.1. The software was used to derive catchment characteristics (e.g., watershed boundary, drainage area, slope, flow path, etc.) solely based on the spatial data inputs [13]. Watershed delineation and spatial arrangement of basin elements (e.g. sub-basin, reach segments and point sources) were defined [14]. The stream drainage lines were created using threshold stream cells of 348,395 . The most popular setup was the sub-basin configuration, where the basin is divided into sub-basin and further sub-divided into hydrologic response units (HRUs) [15]. The minimum 
threshold area of 5/5/5 [\%] for land use/soil class/slope over the sub-basin area was used. The land use, soil and slopes percentage areas covering below the minimum threshold area were excluded, and then the remaining area was redefined so that $100 \%$ of the sub-basin area could be used in the simulation.

HRUs represent the smallest unit areas within the watershed with similar soil, topography, and land-use class [16]. In this study, HRUs definition was done based on eight classes of soil and eight classes of land use and land cover categories, and multiple slope discretization with three slope classes $[<15 \%, 15 \%-30 \%$ and $>30 \%$.

Land use and land cover map were reclassified into SWAT land cover/plant types [17]. Land use and land cover (LULC) of the basin was classified into eight classes and the final land use classes were decided to be assigned as, agriculture land-generic, barren land, current fallow, forest-deciduous, forest-evergreen, sandy area, urban area, and water body (Figure 2). Similarly, the basin's soil was categorized into eight classes (Figure 3).

The Soil Conservation Service Curve Numbers (SCS-CN) were determined based on the USDA National Engineering Handbook [18] [19] [20]. The SCS-CN is a function of the soil permeability, land use, and antecedent soil water conditions. The SCS-CN method is an approach that is used in rainfall-runoff modeling to compute direct runoff. This method assumes an initial abstraction $\left(I_{a}\right)$ before ponding, which is related to the SCS-CN. SCS-CN defines three antecedent moisture conditions: I-dry (wilting point), II-average moisture and III-wet (field capacity) [21]. The SCS-CN method, in SWAT, relates runoff to soil type, land use, and management. The SCS-CN method is based on the principle of water balance and two fundamental assumptions [22].

The first assumption is that the ratio of direct runoff to potential maximum runoff is equal to the ratio of infiltration to potential maximum retention. The second assumption states that the initial abstraction is proportional to the

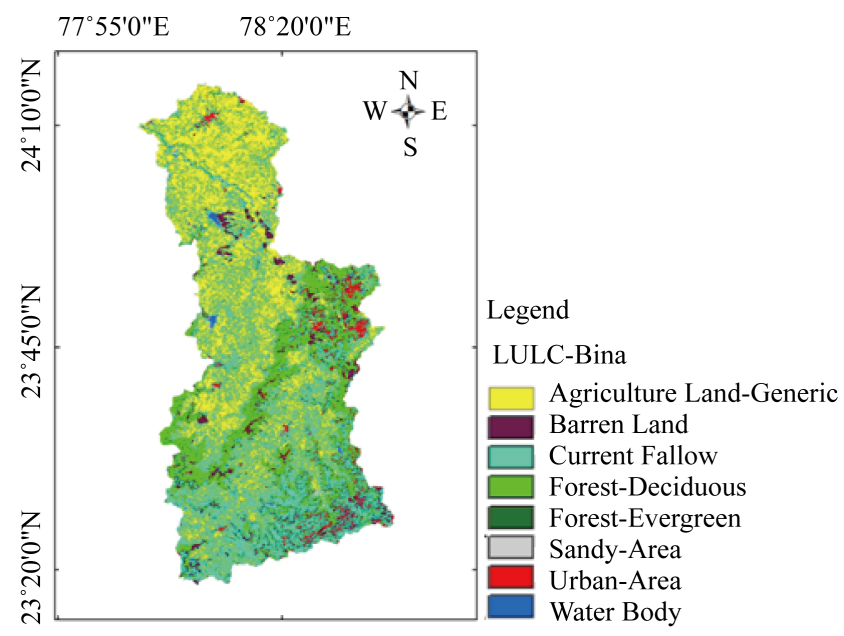

Figure 2. Land use and land cover map (LULC) of Bina River Basin. 


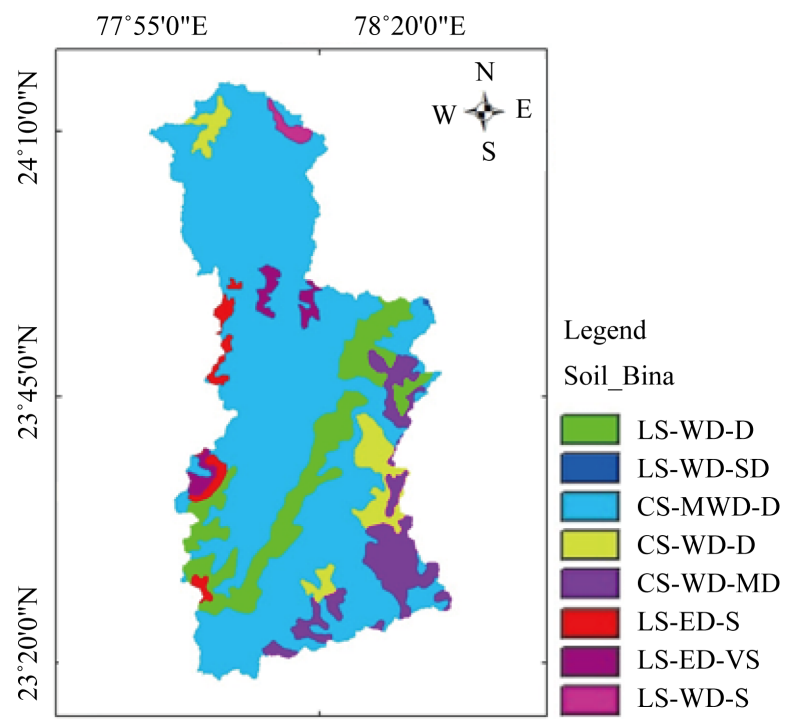

Figure 3. Soil map of the Bina River Basin [CS is Clay Soil, D is Deep, ED is Extremely Drained, LS is Loam Soil, MD is Moderately Deep, MWD is Moderately Well Drained, S is Shallow, SD is Shallow Deep, VS is Very Shallow and WD is Well Drained].

potential maximum retention. The water balance equation and the two assumptions are expressed mathematically [23]:

$$
\begin{aligned}
& P=I a+F+Q \\
& \frac{Q}{P}-I a=F / S \\
& I a=\lambda S
\end{aligned}
$$

where $P$ is the total precipitation $(\mathrm{mm}), I a$ is the initial abstraction before runoff $(\mathrm{mm}), F$ is the cumulative infiltration after runoff begins $(\mathrm{mm}), Q$ is direct runoff $(\mathrm{mm}), S$ is the potential maximum retention $(\mathrm{mm})$, and $\lambda$ is the initial abstraction coefficient. The combination of Equations (1) and (2) leads to the popular form of the original SCS-CN method [24]:

$$
\begin{gathered}
Q=\frac{(P-I a)^{2}}{(P-I a)+S} \text { when } P>I a \\
Q=0 \text {, when } P \leq I a \\
\quad S=\frac{25400}{C N}-254
\end{gathered}
$$

where the $C N$ is a dimensionless variable, ranging from 0 to 100 and it depends on land use, hydrological soil group, hydrologic conditions, and antecedent moisture conditions [25]. This increases accuracy and gives a much better physical description of the water balance. The hydrologic cycle as simulated by SWAT is based on the water balance equation [26]:

$$
S W t=S W o+\left(R_{\text {day }}-Q_{\text {surf }}-E_{a}-W_{\text {seep }}-Q_{g w}\right)
$$


where $S W t$ is soil $\mathrm{H}_{2} \mathrm{O}$ content $(\mathrm{mm})$ at time $t$ in days, $S W o$ is the initial soil $\mathrm{H}_{2} \mathrm{O}$ content $(\mathrm{mm}), R_{d a y}$ is amount of rainfall on day $i(\mathrm{~mm}), Q_{\text {surf }}$ is the amount of surface runoff on day $i(\mathrm{~mm}), E_{a}$ is the amount of evapotranspiration on day $i$ $(\mathrm{mm}), W_{\text {seep }}$ is the amount of percolation and bypass exiting the soil profile bottom on day $i(\mathrm{~mm}), Q_{g w}$ is the amount of return flow on day $i(\mathrm{~mm})$.

\subsubsection{Model Calibration and Validation}

The SWAT model was run both on a daily and monthly timesteps. A two-year model warm-up period (1989 and 1990) was used. Model sensitivity analysis, model calibration and validation were done using the SWAT-CUP tool. Eighteen parameters were considered and tested for the model parameterization and sensitivity analysis. The model uncertainties have been tested and analyzed using the SUFI-2 uncertainty analysis procedure in SWAT-CUP [27] [28].

The parameters were related to stream-flow assessment and include viz. r_CN2.mgt (curve number), v_ALPHA_BF.gw (base flow alfa factor), v_GW_DELAY.gw (groundwater delay time), v_GWQMN.gw (threshold depth of water in shallow aquifer required for return flow), v_GW_REVAP.gw (groundwater 'revap' coefficient), v_ESCO.hru (soil evaporation compensation factor), v_CH_N2.rte (manning roughness for the main channel), v__CH_K2.rte (effective hydraulic conductivity in main conductivity), $\mathrm{r}_{-}$SOL_ AWC.sol (soil available water capacity), r_SOL_K.sol (soil hydraulic conductivity) v_RCHRG_DP.gw (Deep aquifer percolation fraction), r_SOL_BD.sol (Moist bulk density), r_SOL_Z.sol (Depth from the soil surface to bottom of the layer), r_SLSUBBSN.hru (Average slope length), r_OV_N.hru (Manning's "n" value for overland flow), CANMX.hru (Maximum canopy storage), v_EPCO.hru (Plant uptake compensation factor), v_SURLAG.bsn (Surface runoff lag time) have been considered for model parameterization and calibration and validation process.

\subsubsection{Model Evaluation Criteria}

A variety of verification criteria that could be used for the evaluation of models were proposed by the World Meteorological Organization (WMO) and other investigators [29]. Model evaluation was conducted using selected statistical evaluation metrics. The following model evaluation techniques were chosen to check the performance of the SWAT model. Moriasi et al. [30] recommended the use of the coefficient of determination $\left(R^{2}\right)$ together with the Nash-Sutcliffe model efficiency coefficient (NSE) to evaluate the performance of the SWAT model. The $\mathrm{R}^{2}$ (Equation (7)) value is a measure of the strength of the linear correlation between the predicted and observed values. The NSE (Equation (8)) is a measure of the predictive power of the model and is the most frequently used method for hydrological applications [31].

$$
\mathrm{R}^{2}=\frac{\sum_{i=1}^{n}\left(O_{i}-O\right)\left(P_{i}-\bar{P}\right)}{\sqrt{\sum_{i=1}^{n}\left(O_{i}-\bar{O}\right)^{2}} \sqrt{\sum_{i=1}^{n}\left(P_{i}-\bar{P}\right)^{2}}}
$$




$$
\mathrm{NSE}=1-\frac{\sum_{i=1}^{n}\left(O_{i}-P_{i}\right)^{2}}{\sum_{i=1}^{n}\left(O_{i}-\bar{O}\right)^{2}}
$$

where $O_{i}$ is $I^{\text {th }}$ observed streamflow; $\bar{O}$ is mean observed streamflow; $P_{i}$ is $I^{\text {th }}$ predicted streamflow and; $\bar{P}$ is mean predicted streamflow values and, $n$ is the total number of observations.

An NSE value of 1 indicates a perfect match between simulated and observed data. A value of 1 for the $\mathrm{R}^{2}$ also indicates a perfect linear correlation between simulated and observed data. In addition, Percent bias (PBIAS, Equation (9)), which measures the average tendency of the simulated data to be larger or smaller than their observed counterparts, was used in this study. The optimal value of PBIAS is 0.0 , which indicates accurate model simulation. Positive PBIAS values indicate model underestimation bias, and negative values indicate model overestimation bias [30].

$$
\text { PBIAS }=\frac{\sum_{i=1}^{n}\left(O_{i}-P_{i}\right) *(100)}{\sum_{i=1}^{n} O_{i}}
$$

\subsubsection{Sensitivity Analysis}

The global sensitivity of streamflow parameters has been estimated by calculating multiple regression system, which regresses the Latin hypercube generated parameters against the objective function values. The $t$-stat and $p$-value are two factors commonly used to evaluate the sensitivity of model parameters in SWAT-CUP. The t-stat provides a measure of sensitivity as its absolute values go larger while the $\mathrm{p}$-values determine the significance of the sensitivity magnitudes with close to zero value as more significant [32].

\section{Results and Discussion}

\subsection{Catchment Characteristics}

\subsubsection{Hydrological Response Units (HRUs)}

The elevation of the basin ranges from $380-710 \mathrm{~m}$. Among the land use and soil type classes, Forest-Deciduous and Clay Soil-Moderately Well Drained-Deep (CS-MWD-D) were dominant in the catchment, respectively (Table 1). Most (98\%) of the catchment area has a flat to the moderate slope ( $0 \%-15 \%)$. The catchment was divided into four sub-basins and classified into 68 HRUs (Table 2). The HRUs of this basin have been classified into different classes mainly based on land use land cover, soil type, and slope.

The catchment has an average $\mathrm{CN}$ of 83.3 (Table 3). Higher $\mathrm{CN}$ indicates greater run-off potential. Curve number is governed by land use, hydrological soil group, hydrologic conditions, and antecedent moisture conditions which depend on the average slope of the basin.

\subsubsection{The Sensitivity of Model Parameters}

The SWAT model has over 30 parameters. Arnold et al. [33] categorized SWAT model parameters by the process such as surface runoff, baseflow, sediment and 
Table 1. Detail of LULC, soil, and slope.

\begin{tabular}{|c|c|c|c|}
\hline LULC Category & LULC Class & Area [ha] & Watershed area (\%) \\
\hline Sandy Area & SND & 124.74 & 0.05 \\
\hline Forest-Evergreen & FRSE & 489.24 & 0.18 \\
\hline Current fallow in District Sagar & E137 & 33197.85 & 12.01 \\
\hline Forest-Deciduous & FRSD & 72464.22 & 26.21 \\
\hline Water body & WATR & 48421.8 & 17.52 \\
\hline Urban Area & SETL & 37851.3 & 13.69 \\
\hline Barren Land & BARN & 34492.23 & 12.48 \\
\hline Agricultural Land-Generic & AGRL & 49388.94 & 17.87 \\
\hline Soil Category & Soil class & Area [ha] & Watershed area (\%) \\
\hline $\begin{array}{l}\text { Clay soil-Moderately Well } \\
\text { Drained-Deep }\end{array}$ & CS-MWD-D & 199204.1 & 72.06 \\
\hline Clay Soil-Well Drained-Drained & CS-WD-D & 12556.62 & 4.54 \\
\hline $\begin{array}{c}\text { Clay Soil-Well Drained-Moderately } \\
\text { Deep }\end{array}$ & CS-WD-MD & 20497.05 & 7.41 \\
\hline $\begin{array}{l}\text { Loam Soil-Extremely } \\
\text { Drained-Shallow }\end{array}$ & LS-ED-S & 4614.57 & 1.67 \\
\hline $\begin{array}{l}\text { Loam Soil-Extremely Drained-Very } \\
\text { Shallow }\end{array}$ & LS-ED-VS & 5021.19 & 1.82 \\
\hline Loam Soil-Well Drained-Deep & LS-WD-D & 32758.02 & 11.85 \\
\hline Loam Soil-Well Drained-Shallow & LS-WD-S & 1718.82 & 0.62 \\
\hline $\begin{array}{c}\text { Loam Soil-Well Drained-Shallow } \\
\text { Deep }\end{array}$ & LS-WD-SD & 59.94 & 0.02 \\
\hline Slope Category & Slope class (\%) & Area [ha] & Watershed area (\%) \\
\hline 1 & $0-15$ & 271009.8 & 98.04 \\
\hline 2 & $15-30$ & 5158.89 & 1.87 \\
\hline 3 & $30-99.99$ & 261.63 & 0.09 \\
\hline
\end{tabular}

Table 2. Hydrological response units (HRUs) classification.

\begin{tabular}{cccc}
\hline \multirow{2}{*}{ Sub } & \multicolumn{2}{c}{ Sub basin Input Summary } & HRUs \\
\cline { 2 - 3 } & Latitude & Elevation $(\mathrm{m})$ & \\
\hline 1 & 24.07 & 411 & 6 \\
3 & 23.79 & 449 & 20 \\
4 & 23.8 & 483 & 19 \\
& 23.52 & 543 & 23 \\
\hline
\end{tabular}


Table 3. Bina River Basin hydrological components value.

\begin{tabular}{ccc}
\hline $\mathbf{8}$ & Hydrological parameters & Value (mm) \\
\hline 1 & Precipitation & 1210.2 \\
2 & Surface runoff & 225.8 \\
3 & Lateral flow & 0.62 \\
4 & Groundwater & 12.51 \\
5 & Evaporation from shallow aquifer & 0.82 \\
6 & Recharge to deep aquifer & 0.7 \\
7 & Total aquifer recharge & 14.04 \\
8 & Total water yield & 237.92 \\
9 & Percolation to shallow aquifer & 13.13 \\
10 & Actual evapotranspiration & 978.9 \\
11 & Potential evapotranspiration & 2256.1 \\
12 & Transmission Losses & 1 \\
13 & Average curve number & 83.3 \\
\hline
\end{tabular}

nutrient and pesticide using the report of input parameters in SWAT model calibration for 64 selected watershed studies.

In this study, following a comprehensive literature review, 18 parameters were selected for model simulation on daily and monthly timesteps. The parameters primarily represented the channel, runoff and soil processes. The initial value ranges used for these selected parameters are shown in Table 4. It was observed that using the fitted parameters and their appropriate initial range had a significant effect on the streamflow simulation process.

There are mainly two approaches to analyze the sensitivity of model parameters: local sensitivity analysis and global sensitivity analysis. The local sensitivity analysis is a one-at-a-time (OAT) technique that analyses the impact of a single parameter at a time, keeping the other parameters fixed [9]. The global sensitivity of model parameters has been estimated by calculating the multiple regression system, which regresses the Latin hypercube generated parameters against the objective function values [32]. In the present study, the most sensitive parameters observed after global sensitivity analysis for daily and monthly calibration in SUFI-2 are shown in Table 5 and Table 6, respectively. Results showed that r_SOL_BD.sol (moist bulk density), v__ALPHA_BF.gw (base flow alfa factor) and $\mathrm{v} \_$CH_N2.rte (Manning roughness for the main channel) for a daily basis and r_SOL_AWC.sol (soil available water capacity), r_SOL_Z.sol (Depth from the soil surface to bottom of the layer) and r_CN2.mgt (curve number) for monthly simulations were found the most sensitive model parameters. It was experienced that the streamflow simulations process was not affected by parameters that are relatively insensitive compared to sensitive parameters and changes in their range had not caused significant changes in the model result. 
Table 4. Selected parameters and their initial range.

\begin{tabular}{|c|c|c|c|c|}
\hline Sr.no & Parameter_Name & Description of parameters & Min_value & Max_value \\
\hline 1 & R__CN2.mgt & Curve number & -0.2 & 0.2 \\
\hline 2 & V__ALPHA_BF.gw & Baseflow alfa factor & 0 & 1 \\
\hline 3 & V__GW_DELAY.gw & Groundwater delay time & 30 & 450 \\
\hline 4 & $\mathrm{R} \_$SOL_K (..).sol & Soil hydraulic conductivity & -25 & 25 \\
\hline 5 & V_EPCO.hru & Plant uptake compensation factor & 0.01 & 1 \\
\hline 6 & R__SOL_BD (..).sol & Moist bulk density & -25 & 25 \\
\hline 7 & V__OV_N.hru & Manning's " $n$ " value for overland flow & 0.01 & 30 \\
\hline 8 & V__SURLAG.bsn & Surface runoff lag time & 1 & 24 \\
\hline 9 & V_CANMX.hru & Maximum canopy storage & 0 & 10 \\
\hline 10 & R__SOL_Z (..).sol & Depth from soil surfaces to bottom of the layer & -25 & 25 \\
\hline 11 & V__CH_K2.rte & Effective hydraulic conductivity & 0 & 150 \\
\hline 12 & V__CH_N2.rte & Manning roughness for main channel & 0 & 0.3 \\
\hline 13 & R__SLSUBBSN.hru & Average slope length & 10 & 150 \\
\hline 14 & V__GW_REVAP.gw & Groundwater "revap" coefficient & 0.02 & 0.2 \\
\hline 15 & R__SOL_AWC (..).sol & Soil available water capacity & -25 & 25 \\
\hline 16 & V__RCHRG_DP.gw & Deep aquifer percolation fraction & 0 & 1 \\
\hline 17 & V_ESCO.hru & Soil evaporation compensation factor & 0.01 & 1 \\
\hline 18 & A__GWQMN.gw & Threshold depth of water in the shallow aquifer. & 0 & 200 \\
\hline
\end{tabular}

$\mathrm{V}=$ Replaced by value, $\mathrm{R}=(1+$ multiply by value $(\%))$ and $\mathrm{A}=$ added on value.

Table 5. Ranking the sensitivity of streamflow parameters in Bina watershed for daily timescale (the ranking is based on the absolute value of the $\mathrm{t}$-statistics).

\begin{tabular}{|c|c|c|c|}
\hline Rank & Parameters & t-stat & $\mathrm{p}$-value \\
\hline 1 & r_SOL_BD.sol & 14.76 & 0.00 \\
\hline 2 & v_ALPHA_BF.gw & 3.97 & 0.00 \\
\hline 3 & v__CH_N2.rte & -3.93 & 0.00 \\
\hline 4 & r_SOL_Z.sol & -3.42 & 0.00 \\
\hline 5 & v_SURLAG.bsn & 1.78 & 0.08 \\
\hline 6 & v__CH_K2.rte & 1.76 & 0.08 \\
\hline 7 & r__SOL_K.sol & 1.29 & 0.20 \\
\hline 8 & v__GW_DELAY.gw & 1.20 & 0.23 \\
\hline 9 & r_SLSUBBSN.hru & 1.05 & 0.30 \\
\hline 10 & r__SOL_AWC.sol & -0.73 & 0.47 \\
\hline 11 & v_CANMX.hru & 0.66 & 0.51 \\
\hline 12 & v_RCHRG_DP.gw & 0.62 & 0.54 \\
\hline 13 & r_CN2.mgt & 0.27 & 0.79 \\
\hline 14 & v_EPCO.hru & -0.22 & 0.83 \\
\hline 15 & v__GWQMN.gw & 0.15 & 0.88 \\
\hline 16 & r_OV_N.hru & 0.12 & 0.90 \\
\hline 17 & v__ESCO.hru & -0.03 & 0.98 \\
\hline
\end{tabular}


Table 6. Ranking the sensitivity of flow parameters in Bina Watershed for monthly timescale (the ranking is based on the absolute value of the $\mathrm{t}$-statistics).

\begin{tabular}{|c|c|c|c|}
\hline Rank & Parameters & t-stat & p-value \\
\hline 1 & r_SOL_AWC.sol & 12.75 & 0.00 \\
\hline 2 & r_SOL_Z.sol & 8.30 & 0.00 \\
\hline 3 & r_CN2.mgt & -3.37 & 0.00 \\
\hline 4 & v_ESCO.hru & 2.16 & 0.03 \\
\hline 5 & v__ALPHA_BF.gw & 2.12 & 0.03 \\
\hline 6 & v_EPCO.hru & -2.07 & 0.04 \\
\hline 7 & v_CANMX.hru & 1.81 & 0.07 \\
\hline 8 & v_RCHRG_DP.gw & 1.72 & 0.09 \\
\hline 9 & r__SOL_K.sol & -1.72 & 0.09 \\
\hline 10 & v__CH_K2.rte & -1.34 & 0.18 \\
\hline 11 & v__GW_DELAY.gw & 0.75 & 0.46 \\
\hline 12 & r_SOL_BD.sol & 0.66 & 0.51 \\
\hline 13 & r_SLSUBBSN.hru & 0.66 & 0.51 \\
\hline 14 & v__GW_REVAP.gw & 0.65 & 0.52 \\
\hline 15 & v__CH_N2.rte & -0.22 & 0.82 \\
\hline 16 & v_GWQMN.gw & -0.16 & 0.87 \\
\hline 17 & r_OV_N.hru & -0.08 & 0.93 \\
\hline 18 & v_SURLAG.bsn & -0.06 & 0.96 \\
\hline
\end{tabular}

These results were supported by various authors i.e. Singh et al. [34] calibrated SWAT model for Tungabhadra River and found $\mathrm{CH} \_\mathrm{K} 2$, SOL_K, CN2, ALPHA_BF, ALPHA_BNK as most sensitive parameters. Setegn et al. [35] simulated streamflow using the SWAT model in the Lake Tana Basin, in their study, they have evaluated the relative sensitivity of the Nineteen parameters and found that soil evaporation compensation factor (ESCO), initial SCS Curve Number II value (CN2) and base flow alpha-factor (Alpha_Bf) [days] were the most sensitive parameters. Himanshu et al. [36] indicated that a total of 27 sensitive parameters were considered collectively for runoff and sediment, and their rank was determined according to sensitivity to the output. Sensitivity analysis shows that curve number (CN2) and effective hydraulic conductivity (Ch_K2) are the most sensitive model parameters for both runoff and sediment yield computations. Soil evaporation compensation factor (Esco), an available water capacity of soil layer (Sol_Awc), depth from the soil surface to bottom of (Sol_Z) are relatively more sensitive to runoff but less to sediment. Hosseini et al. [10] applied the SWAT model for the runoff estimation in a Taleghan basin and found that the Baseflow alpha factors (ALPHA_BF) followed by Snowfall temperature (SFTMP) and Groundwater delay time (GW_DELAY) are more sensitive parameters. 


\subsubsection{Streamflow Simulation}

Overall, the SWAT model performed "satisfactorily" during daily simulations while during the monthly simulation the model performed "very good". The PBIAS for both daily and monthly time periods was in the acceptable range; with $2.2 \%$ and $18 \%$ for calibration and $4.5 \%$ and $3.9 \%$ for validation, respectively [30]. The coefficients of determination $\left(\mathrm{R}^{2}\right)$ of calibration for the daily and monthly data were 0.66 and 0.96 , respectively. The $\mathrm{R}^{2}$ value of both daily and monthly timescales shows there is a good correlation between the observed and simulated flows [30]. However, it was clear that the model's performance significantly improved with monthly simulations. Similarly, NSE values for monthly simulations both during calibration and validation showed significant improvements compared to respective daily simulations. These are related studies that could support our results: Jain and Sharma. [37] found that the SWAT model could be employed for simulation of runoff and sediment yield behavior of the Vamsadhara river basin. Srinivas G and Naik [38] reported that the SWAT model gave good correlation during daily simulation results and a very good correlation for monthly time series at the Musi river basin. Jain et al. [39] reported that the SWAT model was calibrated and validated with daily streamflow data and the results were indicated a good simulation of streamflow of the Himalayan mountain basin.

The $\mathrm{R}^{2}$ and NS coefficient are two important statistical analyses for the evaluation of the results. According to Santhi et al. [40], when $\mathrm{R}^{2}$ equals 1 , the regression equation model considered as a perfect fit model, while an $\mathrm{R}^{2}$ value less than 0.5 (near to zero), suggests that the model is not suitable. The strength of the model calibration and uncertainty procedure was also analyzed using the $R$-factor. The $R$-factor values were estimated as 0.22 and 0.52 for the daily and monthly simulations, respectively (Table 7 ). The best model parameters and their value ranges for both daily and monthly model simulations are presented in Table 8 and Table 9. In addition, observed and simulated time series daily and monthly streamflow were plotted for visual comparison to explore how the model performs during peak and low flows (Figures 4-11).

Table 7. Model evaluation objective functions daily and monthly results.

\begin{tabular}{cccccc}
\hline \multirow{2}{*}{ No } & \multicolumn{3}{c}{ Daily } & \multicolumn{3}{c}{ Monthly } \\
\cline { 2 - 6 } & Objective Variables & Calibration & Validation & Calibration & Validation \\
\hline 1 & P-factor & 0.49 & 0.42 & 0.44 & 0.25 \\
2 & R-factor & 0.22 & 0.35 & 0.52 & 0.27 \\
3 & $\mathrm{R}^{2}$ & 0.66 & 0.65 & 0.96 & 0.72 \\
4 & NS & 0.65 & 0.58 & 0.94 & 0.72 \\
5 & bR2 & 0.39 & 0.35 & 0.80 & 0.52 \\
\hline
\end{tabular}


Table 8. Daily best parameters with calibrated values.

\begin{tabular}{ccccc}
\hline Sr.No & Parameter_Name & Fitted_Value & Min_value & Max_value \\
\hline 1 & R__CN2.mgt & -0.2419 & -0.3160 & -0.1754 \\
2 & V__ALPHA_BF.gw & 0.9076 & 0.7660 & 1.2156 \\
3 & V_GW_DELAY.gw & 339.4813 & 282.1209 & 402.8797 \\
4 & V__OV_N.hru & 29.4613 & 25.9809 & 33.5634 \\
5 & V_CCH_N2.rte & 0.0160 & -0.0014 & 0.0415 \\
6 & V_CH_K2.rte & 101.2698 & 73.3829 & 129.7200 \\
7 & A_GWQMN.gw & 20.3172 & 16.3810 & 96.7126 \\
8 & V__RCHRG_DP.gw & 0.3463 & 0.0560 & 0.4220 \\
9 & R_SLSUBBSN.hru & -36.8985 & -44.8489 & -30.5237 \\
10 & V_EPCO.hru & 0.5186 & 0.5173 & 0.9265 \\
11 & V_ESCO.hru & 0.3483 & 0.2250 & 0.4228 \\
12 & V_SURLAG.bsn & 14.8983 & 14.3081 & 19.3521 \\
13 & R__SOL_K(..).sol & 30.8894 & 15.0737 & 39.4429 \\
14 & R__SOL_BD(..).sol & 11.1450 & -7.1659 & 20.9614 \\
15 & R__SOL_Z(..).sol & 22.6821 & 5.6266 & 27.2432 \\
16 & R__SOL_AWC(..).sol & 16.8007 & 15.4220 & 33.8054 \\
17 & V__CANMX.hru & 1.6540 & 1.5581 & 3.1297 \\
\hline
\end{tabular}

Table 9. Monthly best parameters with calibrated values.

\begin{tabular}{ccccc}
\hline Sr.No & Parameter_Name & Fitted_Value & Min_value & Max_value \\
\hline 1 & R__CN2.mgt & -0.1229 & -0.1558 & 0.0814 \\
2 & V__ALPHA_BF.gw & 1.2160 & 0.4104 & 1.2316 \\
3 & V__GW_DELAY.gw & 326.1514 & 210.7675 & 572.4725 \\
4 & R__SOL_K(..).sol & -13.1914 & -43.7799 & 2.0799 \\
5 & V__EPCO.hru & 0.8876 & 0.4905 & 1.4520 \\
6 & R__SOL_BD(..).sol & 16.6925 & -1.1801 & 46.4801 \\
7 & V__OV_N.hru & 3.6721 & 1.9713 & 20.6612 \\
8 & V__SURLAG.bsn & 7.5954 & 7.4032 & 20.2188 \\
9 & V__CANMX.hru & 5.0864 & 3.2640 & 9.7960 \\
10 & R__SOL_Z(..).sol & 40.2362 & -3.1300 & 40.6300 \\
11 & V__CH_K2.rte & 12.9645 & -60.8398 & 79.7398 \\
12 & V_CH_N2.rte & 0.1474 & 0.1036 & 0.3110 \\
13 & R_SLSUBBSN.hru & 112.8324 & 75.1561 & 205.5238 \\
14 & V__GW_REVAP.gw & 0.1150 & -0.0211 & 0.1263 \\
15 & R__SOL_AWC(..).sol & 10.1709 & -5.5300 & 33.4300 \\
16 & V__RCHRG_DP.gw & 0.5795 & 0.1554 & 0.7186 \\
17 & V__ESCO.hru & 1.0107 & 0.4500 & 1.3303 \\
18 & A_GWQMN.gw & 56.5522 & 54.4804 & 163.5196 \\
\hline
\end{tabular}




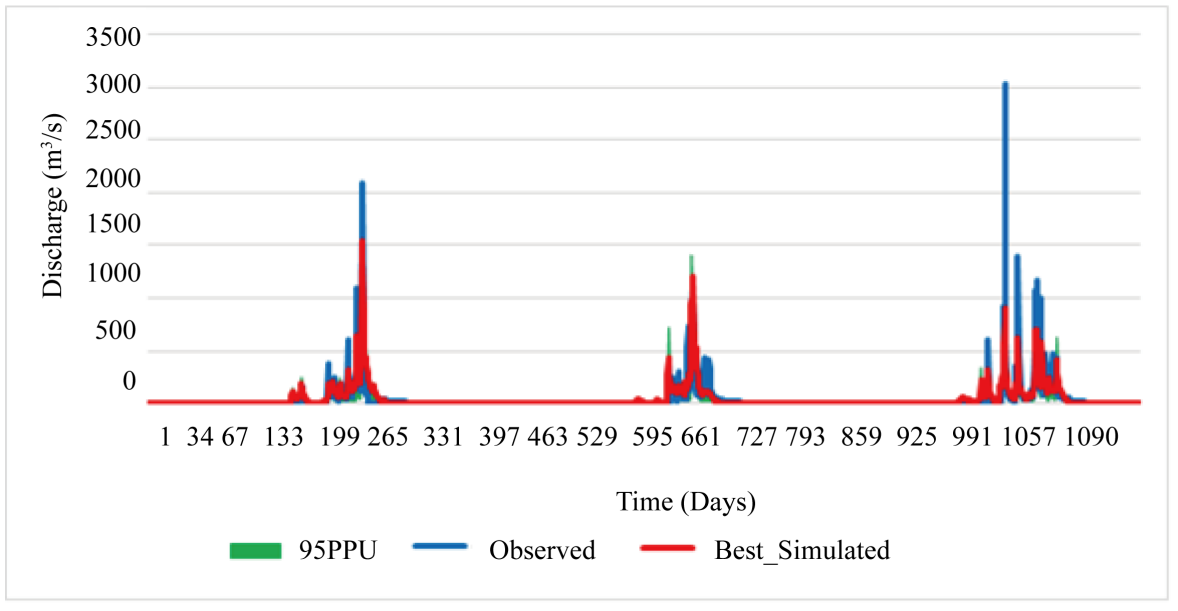

Figure 4. Observed and simulated hydrographs of daily streamflow at the Bina River Basin from 1991 to 1993 (calibration period). The green shaded part is the $95 \%$ prediction uncertainty.

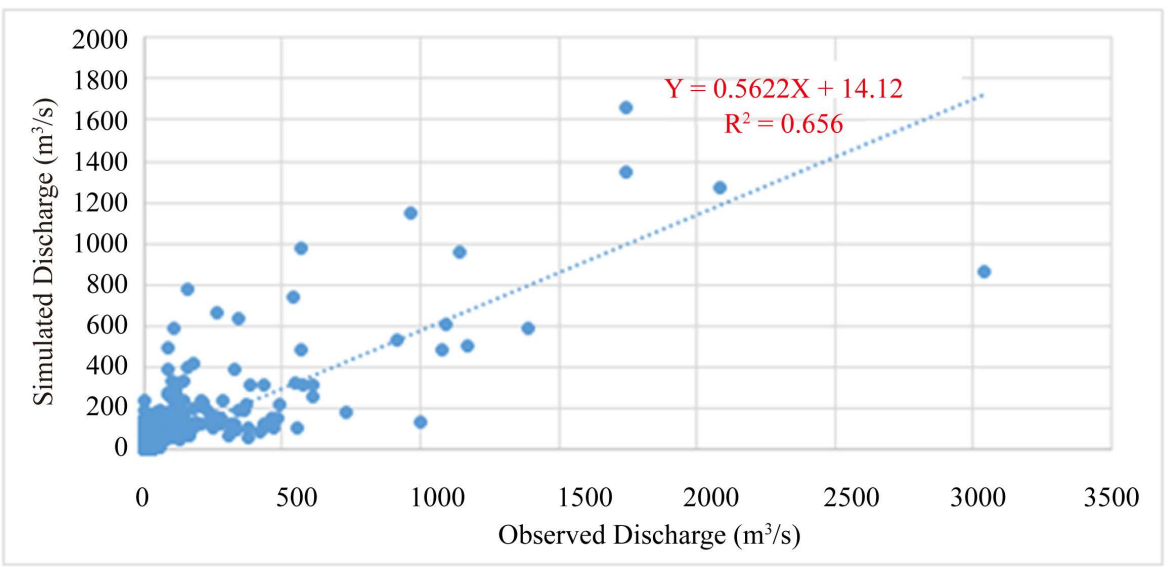

Figure 5. Scatter plot of observed and simulated daily streamflow of the Bina River Basin from 1991 to 1993 (calibration period).

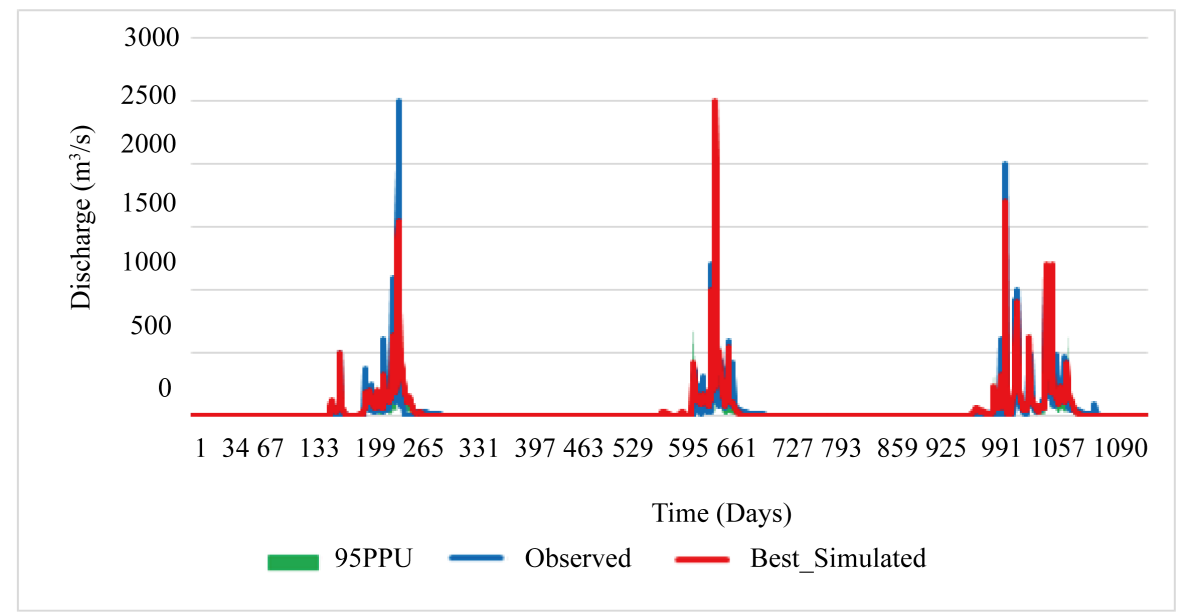

Figure 6. Observed and simulated hydrographs of daily streamflow at the Bina River Basin from 1994 to 1996 (validation period). The green shaded part is the $95 \%$ prediction uncertainty. 


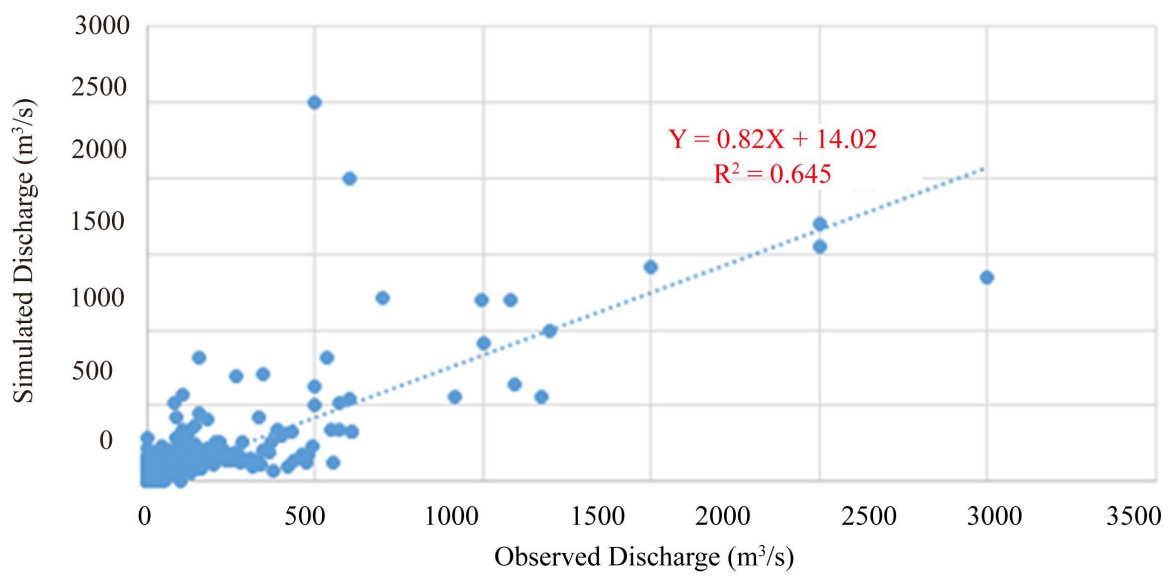

Figure 7. Scatter plot of observed and simulated daily streamflow of the Bina River Basin from 1994 to 1996 (validation period).

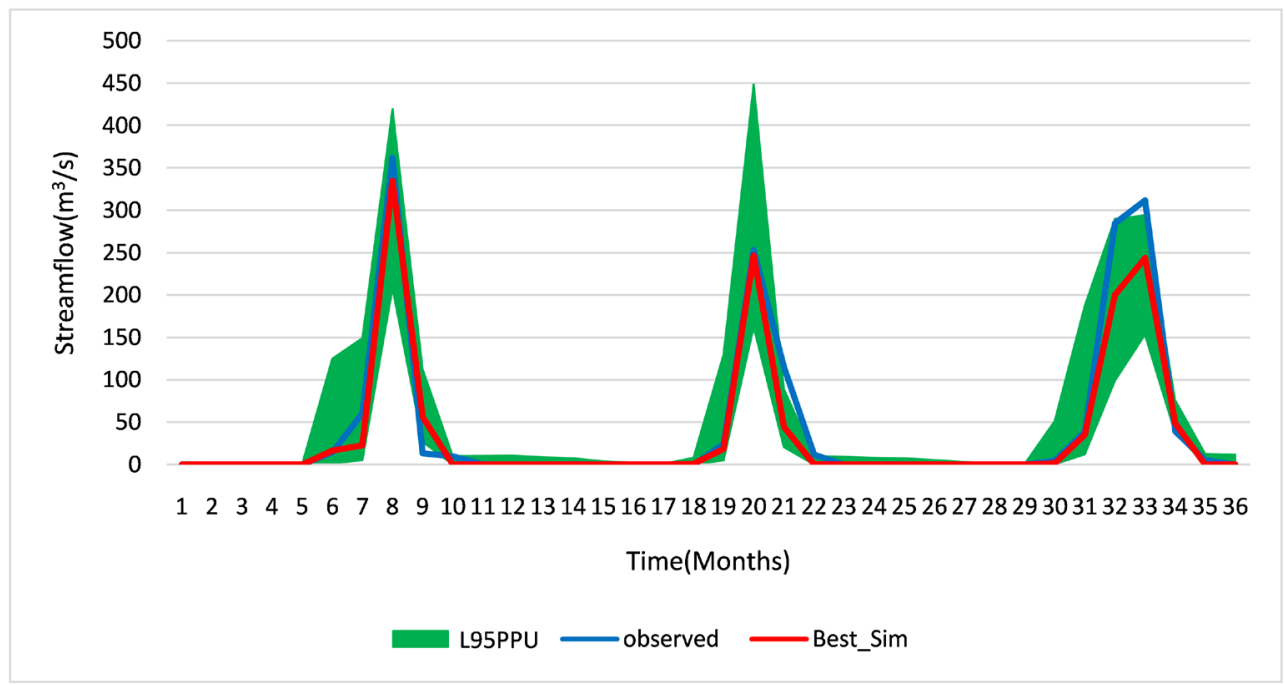

Figure 8. Observed and simulated hydrographs of monthly streamflow at the Bina River Basin from 1991 to 1993 (calibration period). The green shaded part is the 95\% prediction uncertainty.

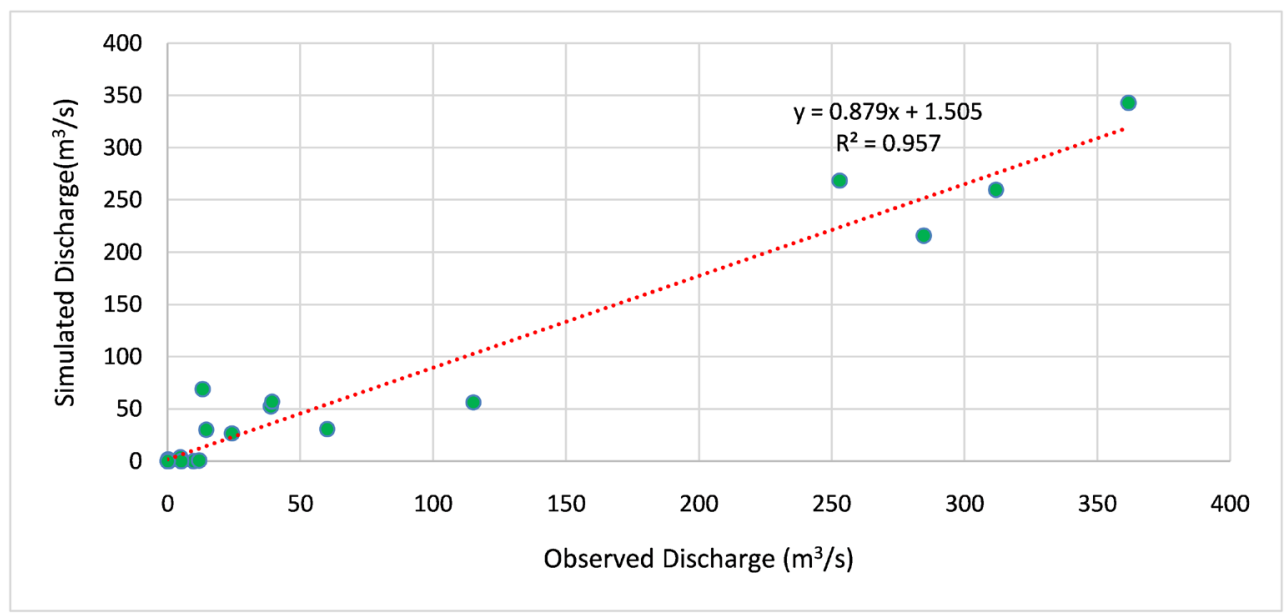

Figure 9. Scatter plot of observed and simulated monthly streamflow of the Bina River Basin from 1991 to 1993 (calibration period). 


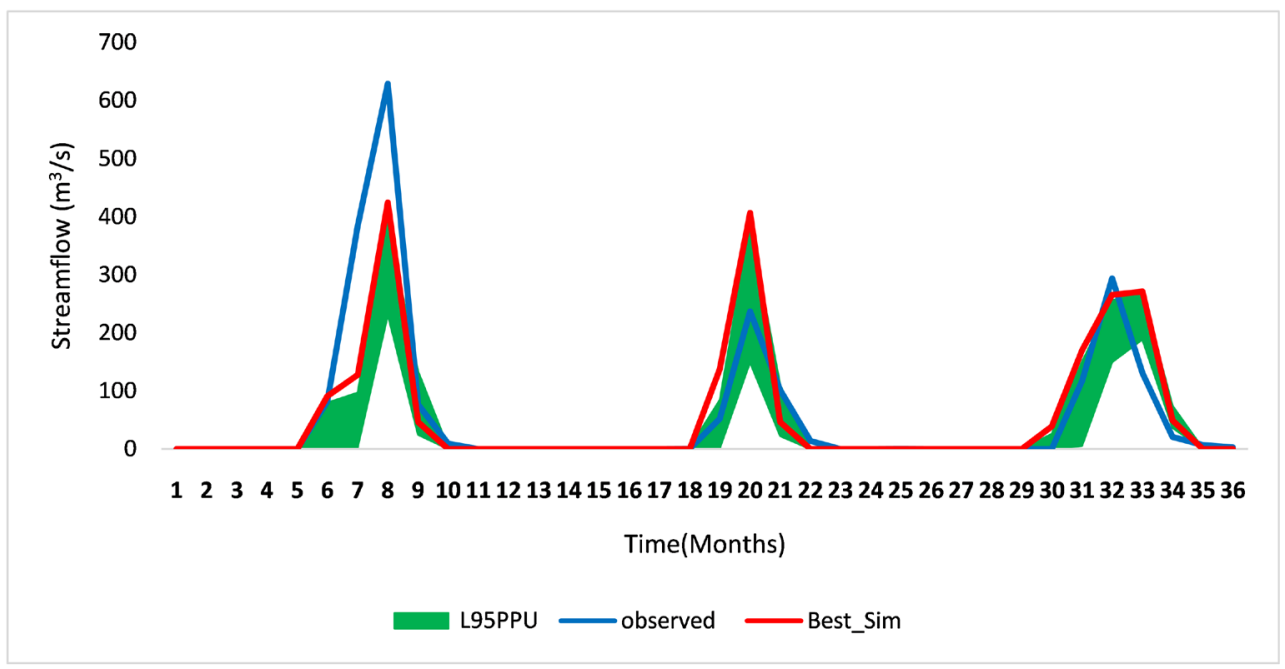

Figure 10. Observed and simulated hydrographs of monthly streamflow at the Bina River Basin from 1994 to 1996 (validation period). The green shaded part is the $95 \%$ prediction uncertainty.

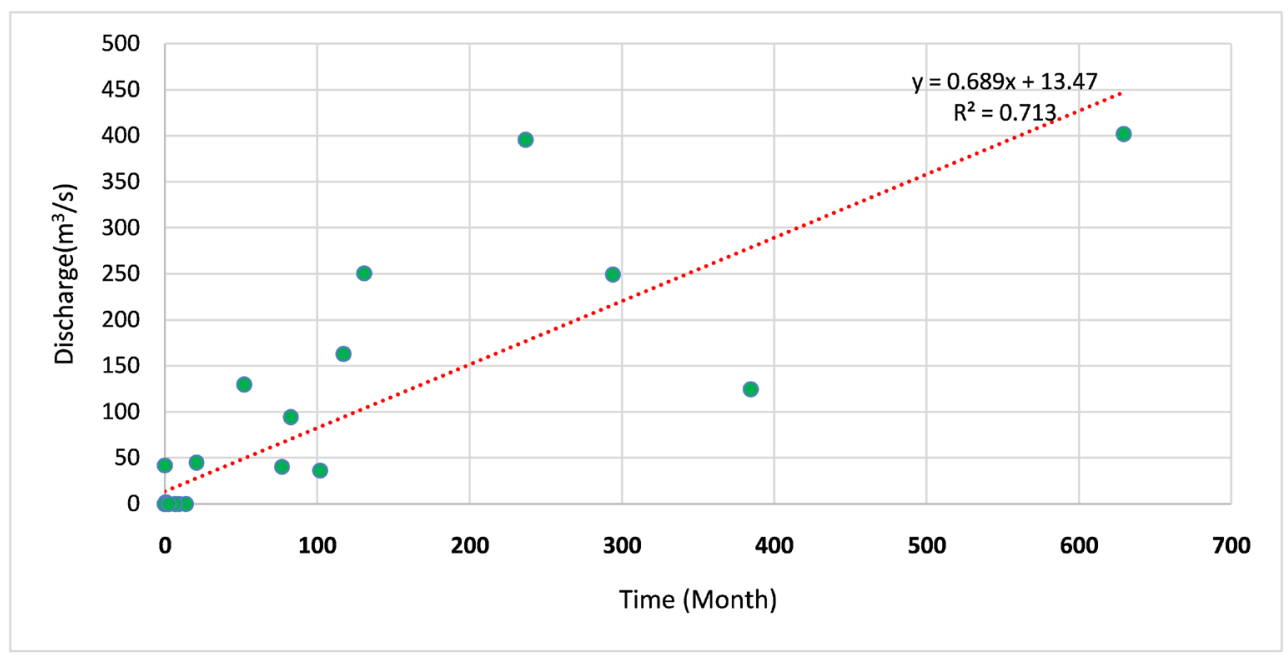

Figure 11. Scatter plot of observed and simulated monthly streamflow of the Bina River Basin from 1994 to 1996 (validation periods).

\section{Conclusions}

Hydrological modeling could be a useful tool for several purposes including water resources planning, development, and management. In this study, the performance of the SWAT model was evaluated in simulating streamflow from the Bina basin. The SWAT-CUP advance calibration and uncertainty analysis tool was used for automatic calibration/uncertainty analysis, validation, and sensitivity analysis of stream-flow measurements on a daily and monthly basis for the period 1989-1996. Results showed that the $\mathrm{R}^{2}$ values for the daily and monthly time steps were 0.66 and 0.96 , respectively during model calibration, while $\mathrm{R}^{2}$ values during the validation period were 0.65 and 0.72 , respectively.

Overall, the SWAT model performed "satisfactory" and "very good" in simulating streamflow at daily and monthly time steps, respectively. The model re- 
produced the observed flow well both during peak and low flow periods. However, the model results showed that prediction uncertainties exist especially with the daily simulations. These uncertainties could be due to the quality of the streamflow records.

This study demonstrated that the SWAT model performed satisfactorily and could be effectively used to simulate streamflow in the Bina river basin, and results could be used to inform decisions towards planning soil and water management practices in the basin.

\section{Acknowledgements}

We thank the National Institute of Hydrology (NIH), Roorkee for providing the facilities to carry out this work. We also thank the staff of NIH for their encouragement and support.

\section{Conflicts of Interest}

The authors declare no conflicts of interest regarding the publication of this paper.

\section{References}

[1] Beven, K. and Robert, E. (2004) Horton's Perceptual Model of Infiltration Processes. Hydrological Processes, 18, 3447-3460. https://doi.org/10.1002/hyp.5740

[2] Perlman, H. Surface Runoff and the Water Cycle. https://www.usgs.gov/special-topic/water-science-school/science/surface-runoff-an d-water-cycle?qt-science_center_objects=0\#qt-science_center_objects

[3] Sitterson, J., Knightes, C., Parmar, R., Wolfe, K., Muche, M. and Avant, B. (2017) An Overview of Rainfall-Runoff Model Types. 30.

[4] European Commission 2015 (2015) Directorate-General for the Environment Guidance Document on the Application of Water Balances for Supporting the Implementation of the WFD: Final. Luxembourg.

[5] Shie-Yui, L., Kwang, P.K. and Vladan, B. (2004) Hydroinformatics. Proceedings of the 6 th International Conference (In 2 Volumes, with Cd-ROM), World Scientific, Singapore.

[6] Chouhan, D.S., Tiwari, H.L. and Galkate, R.V. (2016) Rainfall Runoff Simulation of Shipra River Basin Using AWBM RRL Toolkit.

[7] Cardoso de Salis, H.H., Monteiro da Costa, A., Moreira Vianna, J.H., Azeneth Schuler, M., Künne, A., Sanches Fernandes, L.F. and Leal Pacheco, F.A. (2019) Hydrologic Modeling for Sustainable Water Resources Management in Urbanized Karst Areas. International Journal of Environmental Research and Public Health, 16. https://doi.org/10.3390/ijerph16142542

[8] Arnold, J.G., Srinivasan, R., Muttiah, R.S. and Williams, J.R. (1998) Large Area Hydrologic Modeling and Assessment Part I: Model Development1. JAWRA Journal of the American Water Resources Association, 34, 73-89. https://doi.org/10.1111/j.1752-1688.1998.tb05961.x

[9] Abbaspour, K., Vaghefi, S. and Srinivasan, R. (2017) A Guideline for Successful Calibration and Uncertainty Analysis for Soil and Water Assessment: A Review of Papers from the 2016 International SWAT Conference. Water, 10, 6. 
https://doi.org/10.3390/w10010006

[10] Hosseini, M., Amin, M.S.M., Ghafouri, A.M. and Tabatabaei, M.R. (2011) Application of Soil and Water Assessment Tools Model for Runoff Estimation. American Journal of Applied Sciences, 8, 486-494.

https://doi.org/10.3844/ajassp.2011.486.494

[11] Nayak, T.R., Gupta, S.K. and Galkate, R. (2015) GIS Based Mapping of Groundwater Fluctuations in Bina Basin. Aquatic Procedia, 4, 1469-1476. https://doi.org/10.1016/j.aqpro.2015.02.190

[12] Government of Madhya Pradesh. Water Resources Department Bina Complex Irrigation \& Multipurpose Project.

http://environmentclearance.nic.in/writereaddata/Online/TOR/0_0_11_Sep_2014_1 058196801ExecutiveSummary.pdf

[13] Wagener, T., Wheater, H.S. and Gupta, H.V. (2004) Rainfall-Runoff Modelling in Gauged and Ungauged Catchments. World Scientific, Singapore.

[14] Neitsch, S. (2012) Chapter 1: SWAT Input Data Overview. 30.

[15] M, J., Sudheer, K., Chaubey, I. and Raj, C. (2016) A Generalized Methodology for Identification of Threshold for HRU Delineation in SWAT Model. AGU Fall Meeting Abstracts, 13.

[16] Zarriello, P.J. and Bent, G.C. (2004) A Precipitation-Runoff Model for the Analysis of the Effects of Water Withdrawals and Land-Use Change on Streamflow in the Usquepaug-Queen River Basin, Rhode Island. U.S. Department of the Interior, U.S. Geological Survey. https://doi.org/10.3133/sir20045139

[17] Neitsch, S. (2012) Appendix A: Databases. 60.

[18] King, K.W., Arnold, J.G. and Bingner, R.L. (1999) Comparison of Green-Ampt and Curve Number Methods on Goodwin Creek Watershed Using SWAT. Transactions of the ASAE, 42, 919-926. https://doi.org/10.13031/2013.13272

[19] Mishra, S.K., Babu, P.S. and Singh, V.P. (2007) SCS-CN Method Revisited. 37.

[20] Mockus, V. (1965) National Engineering Handbook Section 4 Hydrology. 127.

[21] Brevnova, E.V. (2001) Green-Ampt Infiltration Model Parameter Determination Using SCS Curve Number (CN) and Soil Texture Class, and Application to the SCS Runoff Model. West Virginia University Libraries.

[22] Mishra, S.K. and Singh, V.P. (2003) Soil Conservation Service Curve Number (SCS-CN) Methodology. Volume 42, Water Science and Technology Library, Springer, Netherlands, Dordrecht. https://doi.org/10.1007/978-94-017-0147-1

[23] Tarboton, D.G. RainfallRunoffProcesses.pdf http://hydrology.usu.edu/RRP/userdata/4/87/RainfallRunoffProcesses.pdf

[24] Essoyéké, B., Isabelle, J.-V. and Musandji, F. (2012) Discussion of "Theory-Based SCS-CN Method and Its Applications" by W. H. Chung, I. T. Wang, and R. Y. Wang. Journal of Hydrologic Engineering, 17, 354-355. https://doi.org/10.1061/(ASCE)HE.1943-5584.0000411

[25] USDA-NRCS stelprdb1044171.pdf. https://www.nrcs.usda.gov/Internet/FSE_DOCUMENTS/stelprdb1044171.pdf

[26] Neitsch, S.L., Arnold, J.G., Kiniry, J.R. and Williams, J.R. (2005) Soil and Water Assessment Tool Theoretical Documentation. 494.

[27] Abbaspour, K.C., Johnson, C. and van Genuchten, M. (2004) Estimating Uncertain Flow and Transport Parameters Using a Sequential Uncertainty Fitting Procedure. Vadose Zone Journal, 3, 1340-1352. https://doi.org/10.2136/vzj2004.1340 
[28] Abbaspour, K.C., Yang, J., Maximov, I., Siber, R., Bogner, K., Mieleitner, J., Zobrist, J. and Srinivasan, R. (2007) Modelling Hydrology and Water Quality in the Pre-Alpine/Alpine Thur Watershed Using SWAT. Journal of Hydrology, 333, 413-430. https://doi.org/10.1016/j.jhydrol.2006.09.014

[29] Nash, J.E. and Sutcliffe, J.V. (1970) River Flow Forecasting through Conceptual Models Part I-A Discussion of Principles. Journal of Hydrology, 10, 282-290. https://doi.org/10.1016/0022-1694(70)90255-6

[30] Moriasi, D.N., Arnold, J.G., Liew, M.W.V., Bingner, R.L., Harmel, R.D. and Veith, T.L. (2007) Model Evaluation Guidelines for Systematic Quantification of Accuracy in Watershed Simulations.

[31] McCuen, R.H., Knight, Z. and Cutter, A.G. (2006) Evaluation of the Nash-Sutcliffe Efficiency Index. Journal of Hydrologic Engineering, 11.

https://www.researchgate.net/publication/253351095_Evaluation_of_the_Nash-Sutc liffe_Efficiency_Index

[32] Abbaspour, K.C. (2015) SWAT Calibration and Uncertainty Programs. 100.

[33] Arnold, J.G., Moriasi, D.N., Gassman, P.W., Abbaspour, K.C., White, M.J., Srinivasan, R., Santhi, C., Harmel, R.D., van Griensven, A., Van Liew, M.W., et al. (2012) SWAT: Model Use, Calibration, and Validation. Transactions of the ASABE, 55, 1491-1508. https://doi.org/10.13031/2013.42256

[34] Singh, V., Bankar, N., Salunkhe, S., Bera, A. and Sharma, J. (2013) Hydrological Stream Flow Modeling on Tungabhadra Catchment: Parameterization and Uncertainty Analysis Using SWAT CUP. Current Science, 104, 1187-1199.

[35] Setegn, S.G., Srinivasan, R. and Dargahi, B. (2008) Hydrological Modelling in the Lake Tana Basin, Ethiopia Using SWAT Model. The Open Hydrology Journal, 2, 49-62. https://doi.org/10.2174/1874378100802010049

[36] Himanshu, S.K., Pandey, A. and Shrestha, P. (2016) Application of SWAT in an Indian River Basin for Modeling Runoff, Sediment and Water Balance. Environ Earth Sci, 76, 3. https://doi.org/10.1007/s12665-016-6316-8

[37] Jain, M. and Sharma, S.D. (2014) Hydrological Modeling of Vamsadhara River Basin, India Using SWAT. 5.

[38] Srinivas, G. and Gopal, M.N. (2017) Hydrological Modeling of Musi River Basin, India and Sensitive Parameterization of Streamflow Using SWAT CUP. Journal of Hydrogeology \& Hydrologic Engineering, 6, 2. https://doi.org/10.4172/2325-9647.1000153

[39] Jain, S.K., Jain, S.K., Jain, N. and Xu, C.-Y. (2017) Hydrologic Modeling of a Himalayan Mountain Basin by Using the SWAT Mode. Hydrol. Earth Syst. Sci. Discuss., 1-26. https://doi.org/10.5194/hess-2017-100

[40] Santhi, C., Arnold, J.G., Williams, J.R., Dugas, W.A., Srinivasan, R. and Hauck, L.M. (2001) Validation of the Swat Model on a Large Rwer Basin with Point and Nonpoint Sources. JAWRA Journal of the American Water Resources Association, 37, 1169-1188. 